Savaş, S. (2014) illköğretim 7. sınıf Türkçe derslerinde mizah kullanımının derse yönelik öğrenci tutumuna etkisi. Ana Dili Eğitimi Dergisi, 2(1), 73-88.

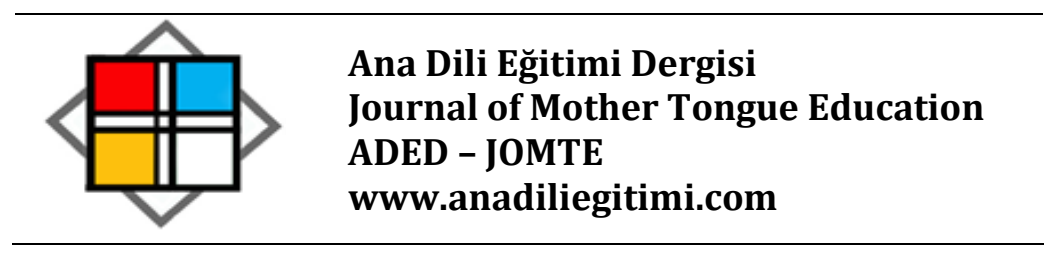

\title{
ilköğretim 7. Sınıf Türkçe Derslerinde Mizah Kullanımının Derse Yönelik Öğrenci Tutumuna Etkisi ${ }^{1}$
}

\author{
Serdar SAVAŞ*
}

\section{Özet}

Bu araştırmada Türkçe dersinde yapılandırmacı yaklaşıma dayalı mizah uygulamalarının öğrencinin Türkçe dersine yönelik tutumlarına etkisinin belirlenmesi amaçlanmıştır. Araştırmada, ön test-son test kontrol gruplu deneysel desen kullanılmıştır. Araştırmada her iki grup için deney öncesi ve deney sonrası ölçüm işlemleri gerçekleştirilmiştir. Bu araştırma, ilköğretim 7. sınıf Türkçe dersi ve 56 öğrenci ile sınırlandırılmıştır. Uygulama, 2008-2009 eğitim-öğretim yılı şubat ve mart aylarında yapılmıştır. Deney ve kontrol grupları üzerinde gerçekleştirilen uygulamalar, kontrol grubunda yapılandırmacı yaklaşıma dayalı karma yöntemlerle, deney grubunda ise yapılandırmacı yaklaşıma dayalı mizah uygulamaları ile sürdürülmüştür. Araştırmada; fıkralar, güldürücü hikâyeler ve anılar, resimler ve karikatürler kullanılmıştır. Deney grubunun Türkçe dersine yönelik tutum puan ortalamaları, kontrol grubunun Türkçe dersine yönelik tutum puan ortalamalarından daha yüksek olmuştur.

Anahtar Kelimler: Türkçe Eğitimi, Mizah, Tutum.

\section{The Effects of the Use of Humor at Seventh Grade on Student Attitude in Turkish Courses}

\section{Abstract}

In this work, it is aimed to determine how humor activities depended on constructive approach affect students' their attitude to Turkish Language Courses. In the research an experimental pattern with pre testpost test were used. Both groups were measured before and after the experiment. This research applied to the seventh grade students of 56 in Turkish Language Courses in February and March in academic year 2008-2009. In control group, blended instruction based on constructive approach was used while in experimental group, humor application depended on constructive approach was used in teaching process. Memories, stories, tales, pictures and cartoons were used in the research. It was found that the experimental group students' attitude toward Turkish Language Course were higher than the attitudes of the control group students on the course.

Key Words: Turkish Teaching, Humor, Attitude.

\footnotetext{
${ }^{1}$ Bu makale, Bülent Ecevit Üniversitesi Sosyal Bilimleri Enstitüsü tarafından kabul edilen "ilköğretim 7. Sınıf Türkçe Derslerinde Mizah Kullanımının Öğrenci Tutum ve Başarısına Etkisi” adlı yüksek lisans tezinden elde edilmiştir.

* Arş. Gör., Bülent Ecevit Üniversitesi, Ereğli Eğitim Fakültesi, Türkçe Eğitimi Bölümü, Kdz.Ereğli/Zonguldak. e-posta: sersavas@gmail.com
} 


\section{Giriş}

Bilgi çağını yaşadığımız günümüzde öğrenme öğretme ortamlarını daha etkili hale getirmek amacıyla çeşitli araştırmalar yapılmakta ve farklı öğrenme yaklaşımları denenmektedir. Yapılan çalışmalar doğrultusunda öne çıkan yaklaşımların başında yapılandırmacı yaklaşım gelmektedir.

Yapılandırmacı yaklaşım öğrenme ortamında insanın nasıl öğrendiği üzerine geliştirilmiş bir yaklaşımdır. Tarihi çok daha eskilere dayanmasına rağmen bugünkü yapısının büyük bir kısmına Piaget ve Bruner'in çalışmalarıyla ulaşmıştır. Başlangıçta öğrenenlerin bilgiyi nasıl öğreneceklerine ilişkin bir kuram olarak gelişmiş ve zaman içinde öğrenenlerin bilgiyi nasıl yapılandırdıklarına ilişkin bir yaklaşım biçimine dönüşmüştür (Demirel, 2004:233). Arslan'a (2007:43) göre yapılandırmacılık, yeni karşılaşılan bilgileri önceki bilgilerle ilişkilendirerek öğrenmek ve böylece daha önceden bildiğimiz konulara bağlı olarak yeni öğrenmeler oluşturmak anlayışına dayalı bir yaklaşımdır.

Yapılandırmacı yaklaşımda öğrenen, öğrenme öğretme sürecinde etkin bir role sahiptir. Bu nedenle yapılandırmacı sınıf ortamı, bilgilerin aktarıldığı bir yer değil; öğrencinin etkin katılımının sağlandığı, sorgulama ve araştırmaların yapııdığı, problemlerin çözüldüğü bir yerdir. Bu yaklaşımda sınıf içi etkinlikler, öğrencilerin zengin öğrenme yaşantıları geçirmelerine olanak sağlayacak şekilde düzenlenmektedir (Demirel, 2004).

Öğrenme öğretme ortamının zenginleştirilmesi ve sürece öğrencinin aktif olarak katılımının sağlanması, ders ve öğrenci açısından önemli görülmektedir. Zenginleştirilen ders ortamı derse yönelik öğrenci ilgisinin artması bakımından da önemlidir. Bunun yanında öğrencilerin kendilerini rahat bir şekilde ifade edebilecekleri sınıf ortamlarının oluşturulması öğrencilerin derse yönelik tutumlarını da etkileyebilecektir. Bu doğrultuda tutum da dersi öğrenmeye yönelik önemli etkenlerden biridir.

Tezbaşaran'a (2008:1) göre tutum, belirli nesne, durum, kurum, kavram ya da diğer insanlara karşı öğrenilmiş, olumlu ya da olumsuz tepkide bulunma eğilimidir. Kavramsal olarak tutum, bireyin kendine ya da çevresindeki herhangi bir nesne, toplumsal konu, ya da olaya karşı deneyim, bilgi, duygu ve güdülerine (motivation) dayanarak örgütlediği zihinsel, duygusal ve davranışsal bir tepki ön eğilimi olarak tanımlanabilir (İnceoğlu, 2010:13).

Ön eğilimler bilgi ve eğitim yoluyla değiştirilebilmektedir. Bu nedenle eğitimde derse yönelik öğrenci tutumları üzerinde farklı alanlarda çalışmalar yapılmaktadır. Yapılan çalışmalarda kullanılan yöntemlerin öğrenci tutumları üzerindeki etkileri belirlenmeye çalışılmaktadır (Deveci, 2002; Akpınar ve Ergin, 2005; Cantürk Günhan, 2006; Kara, 2011; Akçay ve Şahin, 2012). Tutumların değiştiğini ya da değişmediğini tespit eden çalışmalar bulunmaktadır. Araştırmalarda değişmeyen tutumlarla ilgili neden olarak öğrencinin değişime direnç göstermesi ve uzun yıllar aynı dersi ya da konuyu görmeleri gösterilmektedir (Aydın, 2006:164). 
Türkçe dersine yönelik tutumların değiştirilmesinde kullanılabilecek uygulamalardan biri de derslerde mizahın kullanılmasıdır. Mizahın derslerde kullanılması henüz yaygın bir uygulama değildir. Bunun sebebi öğretmenin sınıf ortamında daha fazla enerji harcayacak olması, sınıftaki otoritenin kaybolabileceği düşüncesi, planlamaların zamanında bitmeyebileceği endişesi vb. olabilmektedir. Öğrencilerini hazır bilgi alıcısı gibi görmeyip onları meraklı, oyun canlısı ve yaratıcı insanlar olarak gören öğretmenler, öğrencilerinin düşüncelerle oynadıklarını, sık sık garip sorular sorduklarını, kimi zaman da nükteli sözler sarf ettiklerini göreceklerdir. Böyle bir öğretmen artık öğrettiği şeyi yalnızca tek şekilde anlaşılabilen kuru bir bilgi olarak sunmayacaktır. (Morreall, 1997:139).

Günümüze kadar mizahla ilgili, pek çok farklı tanım yapılmıştır. Tanımlamalar zaman içinde, gelişmelere paralel olarak zenginleşebilir ya da değişebilir. Oral’a (1998:51-52) göre mizah, beklenmedik zamanda, beklenmedik şekilde ortaya çıkan, şaşırtıcı, bir hedefe yönelik, eleştirel bir tepki türüdür.

Mizah bireylerde yaşama sevinci, duyarlılık, empati kurma ve yaşamı çok boyutlu algılama özelliklerini geliştirmektedir. Yazınsal metinlerin dünyasına girme alışkanlığı edinmiş birey, insanların çok çeşitli duyma, düşünme ve hareket etme örnekleriyle tanışır. Kendini başkalarının yerine koyabilen, özdeşim kurma yeteneği oluşmuş bir bireydir artık o. İnsan kişiliğine saygı duyar, hoşgörülüdür. İnsanların değişik özellikte olabileceği gerçeğini anlar. Bu süreç, insanın yeni yaşantılar edinme, kişiliğini değiştirme ve geliştirme sürecidir. Edebiyatın bu işlevine, duyguları geliştirme, duyarlık kazandırma, duygu ve düşünce arasında sağlıklı bir denge kurma da denebilir (Kavcar, 1999:5-6). Mizahın hayal gücü ve yaratıcılıkla olan ilişkisi, bakış açısına getirdiği esneklik yalnızca sanat için değil, tüm eğitim dalları için değerlidir (Morreall, 1997:138).

Eğitimin sınıf ortamında sağlıkı bir şekilde sürdürülebilmesi için öğrencilerin derse motive edilmesi ve güdülenmesi gerekmektedir. Sınıfın havası olumlu ise, yani sınıfta geliştirilen kültürel değerler öğrencide güven havası yaratıyorsa öğrencilerin motivasyonu artar. Sınıfın havası, öğrenciyi cesaretlendiren, başarıya yönelten, rahat bir iletişimin olduğu, öğrencilerin fikirlerini rahatça ifade edebildiği bir şekilde oluşturulmuş ise öğrenci motivasyonu da artmaktadır (Ergün, 2004:112). Motivasyonu artan ve bilinçli bir şekilde ne yapacağını bilen bir öğrenci eğitimin amaçları doğrultusunda istendik davranışları yapmaya güdülenmiş olur. Akün'e (1997:78) göre derste kullanılacak mizah öğeleri ile öğrenciler derse daha çok motive olabilirler.

Sınıflarda mizaha başvurulması öğrencilerin sosyal ilişkilerinin gelişmesi açısından yararlıdır. Mizah, her şeyden önce paylaşımdır. Paylaşımcılık, güvensizlik duygusunun aşılmasında vazgeçilmez bir davranış biçimidir. Paylaşımcılığın birliktelik, içtenlik, arkadaşlık ve dostluk duygularının güçlenmesindeki önemi yadsınamaz. Dahası mizah farklı kültürlerin birbiri anlamasında da bir köprü görevi üstlenebilir (Topçuoğlu, 2007:39).

Mizahı kullanmaktaki amaçlardan bir tanesi yapılan etkinliklerle konuya çağrışımda bulunmak 
ve öğrenciyi konu üzerinde düşündürmektir. Eğitim alanında kullanılacak olan bir mizahî ögenin hem tartışmaya açık olması hem de öğrencide bir eğlenme/gülme/rahatlama hissi uyandırması gerekir (Aydın, 2006:131). Bu sayede olumsuz tutum ve bakış açısı aşılır. Rahatlamış ruh haliyle öğrenmenin daha hızlı, öğrenilenin bellekte kalmasının daha kolay olacağı malumdur. Burada söz edilen durum mizah kahkaha atılsın diye fıkra anlatmak ya da anlattırmak, sulu şakalar yapmak, birilerini gır gıra almak değildir (Topçuoğlu, 2007:39).

Eğitim sürecinde mizahın başarılı olabilmesi için, kişinin öncelikli olarak mizah duygusuna sahip olması gerekir. Çocukluk döneminden itibaren kazanılmaya başlanan mizah duygusu, her geçen dönem birey için daha da önem kazanmaktadır. Bireyin kişilik özellikleri çocuk yaşlarda kazanıldı̆ı̆ndan eğitim-öğretimin ilk basamaklarından itibaren konu üzerinde hassasiyetle durulmalı ve öğrencilere sağlıklı mizah duygusu kazandırılmalıdır. Yapılan araştırmalar mizah eğitimi ile mizah duygusunu geliştirilebileceğini göstermektedir. Küçükbayındır (2003:99), çalışmasında mizah eğitimi alan grupta mizah duygusunun geliştiğini tespit etmiştir. Mizah duygusu gelişmiş olan bir birey, eğitim sürecinde yapılan her türlü etkinliklerden kendine yarar sağlayabilir (Savaş, 2009:83).

Mizah duygusuna sahip olmanın ruh ve beden sağlığına olumlu katkılarda bulunduğu çeşitli araştırmalarda gösterilmektedir. Mizahın beden sağlığı üzeride olumlu rol oynayabileceği halk tarafından çok önceleri sezilmiş ve "bir kahkaha bir kilo pirzolaya bedeldir" özdeyişinin türetilmesine yol açmıştır. İnam ve Güleç'e (2007:59) göre mizahi durumla empati kurabilmek ve bunu dillendirene sempati ile bakabilmek ruhsal açıdan sağlıklı olmanın bir işaretidir.

Cornett (Akt. Özenç, 1998:6), mizah duygusuna sahip olmanın faydalarını on üç maddede sıralar:

1. Dikkati çeker ve düşünceyi harekete geçirir,

2. Yaratıcı yetenekleri ortaya çıkarır,

3. Arkadaş edinmeye yardım eder,

4. Iletişimi kuvvetlendirir,

5. Zor anları yatıştırır,

6. Kültürler arası etkileşimi teşvik eder,

7. Sağlığı güçlendirir,

8. Olumlu tavırlar ve kendine olumlu bir bakış açısı getirir,

9. Motivasyonu artırır ve enerji verir,

10. Sorunları çözer,

11. Öğrencilerin okuma miktarını ve kalitesini artırır,

12. Arzulanan davranışları kuvvetlendirir,

13. Eğlendirici değeri vardır.

Mizah doğru zamanda, doğru yerde ve de etkili bir şekilde kullanılabilirse, bireyde olumlu bir 
bakış açısı kazandırır. Kişinin kendini iyi hissetmesini sağlar, ortamdaki endişelerin yok olmasına yardımcı olur. Okulda öğretmenin yerinde ve zamanında uygulayacağı etkinlik konuyu daha sevimli ve daha eğlenceli kılacaktır. Mizah öğrencileri sakinleştirmek, konuyu basitleştirip resmedebilmek ve motive etmek için de kullanılabilir. Mizah gergin durumlarda sinirleri yumuşatabilir. Öğrenmeye karşı koymayı kısmen de olsa engelleyebilir (Savaş, 2009:84).

Mizahın bir ögesi olan karikatür Sever'e göre, ilköğretim yıllarında Türkçe dersinin temel gereçlerinden biri olması gerekir. Karikatürler çocuğun çok boyutlu düşünme becerisini geliştirir (2003:185). Mizahın eğitimde bilinçli olarak kullanılmasıyla öğrencilere birçok beceri kazandırılabilir. Bunlardan bazılarını Pilancı (1998:27) şu şekilde belirtir:

- Öğrenci topluluk karşısında rahat konuşabilme, konuşurken dinleyenlere zevk verme becerisi kazanır.

- Gülmecelerin her türündeki ses ustalıkları öğrencinin Türkçeyi daha doğru ve işlek kullanmasını sağlar.

- Öğrenci, sözcükleri, deyimleri ve atasözlerini doğru yerde kullanmayı öğrenir.

- Gülmecelerden yararlanmasını öğrenen öğrenci, verdiği örneklerle düşüncelerinin inandırıcılığını kuvvetlendirir.

- Sesini güzel ve etkili kullanma yeteneği kazanır.

Mizahı değişik bakış açılarıyla ele alan ve mizahın farklı özelliklerine değinen çalışmalar mevcuttur. Yapılan değişik çalışmalarda mizahın önemi vurgulanmıştır. Vural'ın (2004) yaptığı araştırmada mizahın insan yaşamındaki önemine, Aydın'ın (2006) yaptığı araştırmada ise mizahın eğitimdeki önemine vurgu yapılmıştır.

Araştırmalarda ilkokuldan üniversiteye kadar çeşitli derslerde ve sınıflardaki öğrencilerin mizaha yönelik tutumları akademik başarıları ve derse yönelik tutumları ele alınmıştır (Topuz, 1995; Çelik, 2006; Üstün,2007; Özkan, 2008). Aydın’ın (2006:162) deneysel çalışmasında, mizah kullanımının öğrencilerin akademik başarılarını arttırmada etkili olduğu belirlenmiştir. Durualp'in (2006:82) çalışmasında da mizah kullanımının öğrencilerin akademik başarılarını arttırmada daha etkili olduğu belirlenmiştir. Derslerde mizah kullanımının akademik başarıyı arttırdığı sonucuna Durmaz (2007:55) da ulaşmıştır. Özalp'in (2006:52) çalışmasında ise mizah ögelerinin kullanımıyla öğrencilerin derse yönelik ilgilerinin arttığı belirtilmiştir. Akün (1997) çalışmasında ilköğretim 4. ve 5. sınıflarda öğrenim gören çocuklarda mizah gelişimi üzerinde durmuştur. Çalışmada anket uygulayarak, sınıflar arasındaki mizah anlayışı farklarını ortay koymuştur. Çalışmada çocukların en çok güldüğü fıkralardan hareketle Türkçe derslerinde ve çocuk kitapları yazımında bunlara yer verilmesi gerektiği vurgulanmıştır. Durmuş (2000) mizah duygusu ve başa çıkma stratejilerini konu alan çalışmasında, mizah duygusu yüksek ve düşük olan öğrenciler arasında iyimser ve kendine güvenli başa çıkma stratejileri yönünden anlamlı farklar olduğunu tespit etmiştir. Belirtilen araştırmalar 
yanında durumluluk mizah tepki düzeyi (İncioğlu, 2003), mizah kullanımı (Yerlikaya, 2003), mizah tarzları (Tümkaya, 2006) gibi konularda da çalışmalar yapılmıştır.

Mizah kullanımı (karikatür, resim, fıkra, espri, vd.) eğlendirirken düşündüren ve öğreten bir yöntemdir. Mizahın kullanımı mizahi düşünebilme becerisi, mizahi anlam, mizahi analiz ve yorum, eleştirel ve yaratıcı düşünme, mizahi araştırma ve mizahi kavramlar gibi becerileri de içerir. Bu becerilerin hepsinin öğrenciye kazandırılması için uzun bir süreç gerektirmektedir. Öğretmen ve öğrenciler tarafından düzenlenecek mizah çalışmalarının, öğrencilerin bu becerileri kazanmalarına katkıda bulunacağı düşünülmektedir.

\section{Araştırmanın Amacı}

Bireylere kazandırılması planlanan istendik özelliklerin daha doğru, sistematik bir şekilde ve kısa sürede kazandırılması eğitim programları vasıtası ile olur. Eğitim programı, öğrenciye okul içinde ve dışında planlanmış etkinlikler yoluyla sağlanan öğrenme yaşantıları düzeneği olarak tanımlanabilir (Demirel, 2004:4). Bu istendik özelliklerin kazandırıması için Milli Eğitim Bakanlığı, 2005-2006 öğretim yılından itibaren ilköğretim 1-8. sınıflarında aşamalı olarak yeni bir program ortaya koymuştur. Milli Eğitim Bakanlığı, bu programın Türkçe 1 - 8. sınıflarında mizahın unsurları olan karikatür, resim, anı ve fıkraya etkinlik olarak az da olsa yer vermiştir. Türkçe öğretiminde mizahın daha geniş bir biçimde işlendiği bir programın 7. sınıf düzeyindeki öğrenciler üzerinde nasıl bir etki yapacağı bu araştırmayı şekillendirmiştir.

\section{Araştırmanın Problemi}

Araştırmanın problem cümlesi, “ilköğretim 7. sınıf Türkçe dersi programında yer alan "Duygu ve Hayaller" teması konularında, mizah uygulamalarıyla yapılan öğretim ile yapılandırmacı yaklaşıma dayalı karma yöntemlerin uygulandığı öğretim arasında öğrencilerin Türkçe dersine yönelik tutumları bakımından anlamlı bir farklılık var mıdır?" şeklinde belirlenmiştir.

Bu problem durumuna bağlı olarak araştırmanın alt problemleri aşağıdaki şekilde belirlenmiştir:

1. Mizah uygulamalarının yapıldığı deney grubundaki ilköğretim 7. sınıf öğrencilerinin Türkçe dersine yönelik tutumları ile karma yöntemlerin uygulandığı kontrol grubundaki öğrencilerin Türkçe dersine yönelik tutumları arasında anlamlı farklılıklar var mıdır?

1.1. Deney grubunun Türkçe dersine yönelik tutum ön test puanları ile kontrol grubunun Türkçe dersine yönelik tutum ön test puanları arasında anlamlı farklılık var mıdır?

1.2. Deney grubunun Türkçe dersine yönelik tutum ön test ve son test puanları arasında son test lehine anlamlı farklılık var mıdır?

1.3. Kontrol grubunun Türkçe dersine yönelik tutum ön test ve son test puanları arasında son test lehine anlamlı farklılık var mıdır? 
Illköğretim 7. Sınıf Türkçe Derslerinde Mizah Kullanımının Derse Yönelik Öğrenci Tutumuna Etkisi

1.4. Deney grubunun Türkçe dersine yönelik tutum son test puanları ile kontrol grubunun Türkçe dersine yönelik tutum son test puanları arasında anlamlı farklıık var mıdır?

1.5. Deney grubunun Türkçe dersine yönelik tutum son test ve ön test puanları arasındaki fark puanları ile kontrol grubundaki öğrencilerin Türkçe dersine yönelik tutum son test ve ön test puanları arasındaki fark puanları arasında anlamlı farklılık var mıdır?

\section{Yöntem}

Araştırmanın konusu olan mizahın eğitimle ilişkilendirilmesinde, yapılan çalışmaların öğrencilerin tutumlarına etkilerini belirlemek amacıyla ön test-son test kontrol gruplu deneysel desen kullanılmıştır. Bu çalışma modeli özellikle deneysel işlemlerin yer aldığı eğitim araştırmalarında en çok kullanılan modeldir (Karasar, 2000:102). Her iki gruba deney öncesi ve deney sonrası ölçümler yapılmıştır. Tablo 1'de deney öncesi ve deney sonrası gruplar üzerinde yapılan ölçümler gösterilmiştir.

Tablo 1: Deneysel Desen

\begin{tabular}{llll}
\hline \multicolumn{1}{c}{ Gruplar } & \multicolumn{1}{c}{ Ön Test } & Deneysel İşlemler & \multicolumn{1}{c}{ Son Test } \\
\hline $\begin{array}{l}\text { Kontrol } \\
\text { Grubu }\end{array}$ & $\begin{array}{l}\text { • Türkçe Dersine Yönelik } \\
\text { Tutum Ölçeği }\end{array}$ & $\begin{array}{l}\text { Yapılandırmacı Yaklaşıma } \\
\text { Dayalı Karma Yöntemler }\end{array}$ & $\begin{array}{l}\text { • Türkçe Dersine Yönelik } \\
\text { Tutum Ölçeği }\end{array}$ \\
$\begin{array}{l}\text { Deney } \\
\text { Grubu }\end{array}$ & $\begin{array}{l}\text { - Türkçe Dersine Yönelik } \\
\text { Tutum Ölçeği }\end{array}$ & $\begin{array}{l}\text { Yapılandırmacı Yaklaşıma } \\
\text { Dayalı Mizah Uygulamaları }\end{array}$ & $\begin{array}{l}\text { - Türkçe Dersine Yönelik } \\
\text { Tutum Ölçeği }\end{array}$ \\
& & &
\end{tabular}

\section{Çalışma Grubu}

Ilköğretim 7. sınıf Türkçe derslerinde mizah kullanımının öğrencinin Türkçe dersine yönelik tutumuna etkisini araştırmak amacıyla yapılan araştırma deney desenli olarak düzenlenmiştir.

Çalışma 2008-2009 eğitim-öğretim yılı bahar yarıyılında, Zonguldak/ Kdz.Ereğli'de gerçekleştirilmiştir. Çalışma grubunu, ilçe merkezinde sosyo ekonomik bakımdan orta düzeyde yer alan, bir illköğretim okulunda 7. sınıfta öğrenim gören 56 öğrenci oluşturmaktadır.

Çalışma 7. sınıflarda iki şubede yapılmıştır. Deney grubunu oluşturan birinci şubenin mevcudu 31 kişi olup 27 kişi denel işleme tabi tutulabilmiştir. Kontrol grubunu oluşturan ikinci şubenin mevcudu 30 kişi olup 29 kişi denel işleme tabi tutulabilmiştir. İki şubede gerçekleştirilen çalışmaya, birinci şubeden 12 kız, 17 erkek; ikinci şubeden ise 14 kı, 13 erkek olmak üzere toplam 56 öğrenci katılmıştır. Diğer öğrenciler haftalık devamsızlık, hastalık vb. nedenlerle deneysel sürece dahil edilmemiştir. Tablo 2'de deney ve kontrol grubu öğrencilerinin özellikleri gösterilmiştir. 
Tablo 2: Örneklemi Oluşturan Deney ve Kontrol Grubundaki Öğrenci Özellikleri

\begin{tabular}{lcc}
\hline & Deney Grubu & Kontrol Grubu \\
\hline Kız & 14 & 12 \\
Erkek & 13 & 17 \\
Toplam & 27 & 29 \\
\hline
\end{tabular}

Tablo 2'ye göre deney ve kontrol grubundaki öğrenci özelliklerinin bir birine yakın oldukları söylenebilir.

\section{Deneysel İşlem Basamakları}

1. Uygulama süresince işlenecek konular saptanmış ve konulara ilişkin hedefler ve kazanımlar Illköğretim Türkçe Dersi Öğretim Programından (MEB, 2006) alınmıştır.

2. Çalışmanın başlangıcında Türkçe dersini işleyecek öğretmene çalışmanın amacı açıklanarak yapılandırmacı yaklaşıma dayalı mizah uygulamaları hakkında gerekli bilgilendirmeler yapılmış, çalışmanın nasıl uygulanacağı anlatılmıştır. Öğretmene uygulamada yararlanacağı araştırmacı tarafından seçilmiş ve hazırlanmış olan karikatür, fıkra, resim ve powerpoint sunumları gösterilmiştir. Bununla birlikte araştırmacı tarafından hazırlanan ders planları da öğretmene verilmiş, ondan ders planı ve uygulamalara dair dönüt istenmiş, öğretmenin görüşleri çerçevesinde gerekli düzeltmeler yapılmıştır.

3. Öğrencilere araştırma hakkında bilgi verilmiştir. Araştırma sırasında uygulanan Türkçe dersine yönelik tutum ölçeğinin araştırmanın amaçlarına ulaşması açısından önemli olduğu anlatılmıştır. Bu nedenle ölçeği cevaplarken samimi olmaları istenmiştir.

4. Uygulama deney ve kontrol gruplarında aynı öğretmen tarafından gerçekleştirilmiş ve haftada beşer saatten yedi hafta sürmüştür.

5. Uygulama boyunca deney grubunda yapılandırmacı yaklaşıma dayalı mizah uygulamaları kullanılmış, dersler temayla ilgili kazanımlar doğrultusunda sınıf ortamında işlenmiştir. Yapılandırmacı yaklaşıma dayalı mizah uygulamaları hakkında deney grubu öğrencilerine bilgi verilmiş ve bu süreçte ne yapmaları gerektiği hakkında gerekli açıklamalar yapılmıştır. Bu doğrultuda öncelikli olarak deney grubundaki öğrencilerin derslere hazırlıklı olarak gelmeleri için çalışma kitaplarında yer alan etkinlikleri önceden araştırarak yapmaları istenmiştir. Öğrencilere çalışmayla ilgili ödevler verilmiştir. Duygu ve Hayaller temasını içeren konularla ilgili araştırmacının uzman görüşlerine başvurarak hazırladığı uygulamalar (fıkra, karikatür, resim powerpoint) derste Türkçe öğretmeni tarafından işlemiştir. Öğrencilerin ders esnasında bilgisayar ve projeksiyon sistemi aracılığıyla ve önlerinde bulunan dokümanlar aracılığıyla konuları görsel ve işitsel olarak işlemeleri ya da araştırmaları sağlanmıştır.

6. Kontrol grubuna araştırmacı tarafından herhangi bir müdahale yapılmamıştır. Uygulama boyunca kontrol grubunda yapılandırmacı yaklaşıma dayalı karma yöntemler uygulanmıştır. Konular ders 
öğretmeni tarafından anlatılarak sınıf ortamında işlenmiştir. Yapılandırmacı yaklaşıma dayalı karma yöntemler içinde anlatım yöntemi, soru-cevap, beyin fırtınası, tartışma gibi yöntem ve tekniklere yer verilmiştir. Konuların gerektirdiği yerlerde performans görevleri verilerek öğrencilerin derslere hazırlıklı gelmeleri sağlanmaya çalışılmıştır. Bu noktada öğrencilerden derse gelmeden önce konulara hazırlanmaları istenmiş ve konu ile ilgili sorular sorularak derse başlanmıştır. Öğrencilerin çalışma kitaplarındaki etkinlikleri önceden yapması sağlanarak derslerde öğrencilerin ön bilgileri yoklandıktan sonra ders öğretmeni tarafından işlenmiştir.

\section{Veri Toplama Araçları}

Bu araştırmada veriler, Türkçe dersine yönelik tutum ölçeği ile toplanmıştır.

Ilköğretim 7. sınıf öğrencilerinin Türkçe dersine yönelik tutumlarını saptamak amacıyla ilgili yayınlar taranmış ve daha önceki çalışmalarda kullanılmış anketler yardımıyla konuyla ilgili maddeler yazılmıştır. Ölçek oluşturulurken Aydın'ın (2006) “Türkçe Dersine Yönelik Tutum Ölçeği”nden yararlanılmıştır. Oluşturulan maddelerin geçerliliği için Türkçe Eğitimi Bölümünden bir, Eğitim Bilimleri Bölümünden de iki uzman görüşü alınmıştır. Kapsam geçerliliğini belirlemede sıkça kullanılan yöntemlerden biri uzman görüşlerine başvurmaktır (Büyüköztürk, 2007:167-168).

Türkçeye yönelik tutum ölçeğini geliştirmek için Gazi Illköğretim Okulu 8/A ve 8/D şubelerinden 49 öğrenciye, Kepez İzmirlioğlu İlköğretim Okulu 8/A ve 8/C şubelerinden 56 öğrenciye, İzmirlioğlu İlköğretim Okulu 8/A ve 8/B şubelerinden 70 öğrenciye, Gülüç Vesile Dikmen İlköğretim Okulu 8/A, 8/B ve 8/C şubelerinden 45 öğrenciye, uygulanmıştır. Bu ölçek toplam olarak illköğretim 8. sınıftan 220 öğrenci üzerinde uygulanmıştır. Pilot ve asıl uygulamada, çalışma gruplarının süreçten etkilenmemesi için tutum ölçeği 8. sınıf öğrencileri üzerinde uygulanarak geliştirilmiştir. Geliştirilen 30 maddelik Likert Tipi ölçekten, elde edilen veriler SPSS programında değerlendirilmiş ve ölçekten madde çıkartılmamıştır. Hesaplamalar doğrultusunda ölçeğin Cronbach alpha güvenirliği 0,83 bulunmuştur.

Türkçe dersine yönelik tutum ölçeğinin puanlamasında olumlu maddelerde tamamen katılıyorum için 5 puan, katılıyorum için 4 puan, kararsızım için 3 puan, katılmıyorum için 2 puan, hiç katılmıyorum için 1 puan verilmiş; olumsuz maddelerde ise tamamen katılıyorum için 1 puan, katılıyorum için 2 puan, kararsızım için 3 puan, katılmıyorum için 4 puan, hiç katılmıyorum için 5 puan verilmiştir.

\section{Verilerin Analizi}

Araştırma sırasında elde edilen verilerin analizi SPSS (13.0) paket programı ile yapılmıştır. Araştırmada alt problemlere cevap ararken bağımlı ve bağımsız gruplar için $t$ testinden yararlanılmıştır. 


\section{Bulgular ve Yorum}

Bu bölümde araştırmanın alt problemlerini incelemek amacı ile yapılan istatistiksel analizlerin değerlendirilmesi sonucunda elde edilen bulgulara ve yorumlara yer verilmiştir. Bulgular ve yorumlar araştırmanın alt problemlerine göre aşağıda sırayla verilmiştir.

\section{Alt Problemlere ilişkin Bulgular ve Yorum}

Araştırmanın alt problemi şu şekilde ifade edilmiştir:

1. Mizah uygulamalarının yapıldığı deney grubundaki ilköğretim 7. sınıf öğrencilerinin Türkçe dersine yönelik tutumları ile karma yöntemlerin uygulandığı kontrol grubundaki öğrencilerin Türkçe dersine yönelik tutumları arasında anlamlı farklılıklar var mıdır?

Birinci probleme ait veriler elde edilirken, öğrencilerin Türkçe dersine yönelik tutumlarına ait verilere göre, deney ve kontrol gruplarının tutum ön test ve son test puanları bağımsız gruplar için $t$ testiyle; deney grubunun tutum ön test, son test puanları ile kontrol grubunun tutum ön test, son test puanları bağımlı gruplar için $t$ testi analizi ile karşılaştırılmıştır. Son olarak deney ve kontrol gruplarının tutum son test fark puanları ile tutum ön test fark puanları arasındaki farklılık yine $t$ testiyle karşılaştırılmıştır. Elde edilen veriler aşağıda sunulmuştur:

1.1. Deney grubunun Türkçe dersine yönelik tutum ön test puanları ile kontrol grubunun Türkçe dersine yönelik tutum ön test puanları arasında anlamlı farklıık var mıdır?

Tablo 3'te, deney ve kontrol grubuna ait Türkçe dersine yönelik tutum ön test puanları gösterilmiştir.

Tablo 3: Deney ve Kontrol Gruplarının Türkçe Dersine Yönelik Tutum Ön Test Puan Ortalamalarının Karşılaştırılmasına iliş̧kin Bağımsız Gruplar İ̧̧in t Testi Analiz Sonuçları

\begin{tabular}{lcccccc}
\hline Grup & $N$ & $\bar{X}$ & $s$ & sd & $t$ & $p$ \\
\hline Deney & 27 & 3,28 & 0,24 & 40 & $-6,10$ & 0,00 \\
Kontrol & 29 & 3,95 & 0,53 & & & \\
\hline
\end{tabular}

Tablo 3 incelendiğinde, uygulamalar başlamadan önce deney grubu öğrencilerinin Türkçe dersine yönelik tutum ön test puanları ortalaması 3,28, kontrol grubu öğrencilerinin Türkçe dersine yönelik tutum ön test puanları ortalamasının ise 3,95 olduğu görülmektedir. Grupların Türkçe dersine yönelik tutum ön test puanları ortalamaları arasında anlamlı bir farkın olup olmadığı, bağımsız gruplar için $t$ testi ile analiz edilmiş, hesaplanan $t$ değeri ve \%95 güven aralığında anlamlılık düzeyine göre gruplar arasında anlamlı bir farklılık gözlenmiştir $(t(40)=-6,10 ; p<0,05)$. Bu sonuca göre çalışma öncesinde deney ve kontrol gruplarının Türkçe dersine yönelik tutumlarının birbirine denk olmadığı söylenebilir. Bu çalışmada düzeyi düşük olan öğrenciler deney grubuna alınarak mizahın etkisinin daha objektif değerlendirilmesi amaçlanmıştır. 
1.2. Deney grubunun Türkçe dersine yönelik tutum ön test ve son test puanları arasında son test lehine anlamlı farklılık var mıdır?

Tablo 4'te deney grubunun Türkçe dersine yönelik tutum ön test ve son test puanlarına ait bilgiler sunulmaktadır.

Tablo 4: Deney Grubunun Türkçe Dersine Yönelik Tutum Ön Test ve Son Test Puanlarına Iilişkin Bağımlı Gruplar için t Testi Analiz Sonuçları

\begin{tabular}{lcccccc}
\hline Test & $N$ & $\bar{X}$ & $s$ & $s d$ & $t$ & $p$ \\
\hline Ön test & 27 & 3,28 & 0,24 & 26 & $-6,92$ & 0,00 \\
Son test & 27 & 4,07 & 0,45 & & & \\
\hline
\end{tabular}

Tablo 4 incelendiğinde, deney grubu öğrencilerinin Türkçe dersine yönelik tutum ön test puanları ortalamasının 3,28 olduğu, tutum son test puanları ortalamasının ise 4,07 olduğu görülmektedir. Deney grubunun Türkçe dersine yönelik tutum ön test ve son test puanları ortalamaları arasında anlamlı bir farkın olup olmadığı, bağımlı gruplar için t testi ile analiz edilmiş, hesaplanan $\mathrm{t}$ değeri ve \%95 güven aralığında anlamlılık düzeyine göre testler arasında anlamlı bir farklılık olduğu belirlenmiştir $(t(26)=-6,92 ; p<0,05)$. Elde edilen bu bulgulara göre, yapılandırmacı yaklaşıma dayalı mizah uygulamalarının öğrencilerin Türkçe dersine yönelik tutumlarını olumlu yönde geliştirmede etkili olduğu söylenebilir.

1.3. Kontrol grubunun Türkçe dersine yönelik tutum ön test ve son test puanları arasında son test lehine anlamlı farklılık var mıdır?

Tablo 5'te kontrol grubunun Türkçe dersine yönelik tutum ön test ve son test puanlarına ait bilgiler sunulmaktadır.

Tablo 5: Kontrol Grubunun Türkçe Dersine Yönelik Tutum Ön Test ve Son Test Puanlarına İlişkin Bağımlı Gruplar için $t$ Testi Analiz Sonuçları

\begin{tabular}{lcccccc}
\hline Test & $\mathrm{N}$ & $\overline{\mathrm{X}}$ & $\mathrm{S}$ & $\mathrm{sd}$ & $\mathrm{t}$ & $\mathrm{p}$ \\
\hline Ön test & 29 & 3,95 & 0,53 & 28 & 0,76 & 0,45 \\
Son test & 29 & 3,85 & 0,55 & & & \\
\hline
\end{tabular}

Tablo 5 incelendiğinde, kontrol grubu öğrencilerinin Türkçe dersine yönelik tutum ön test puanları ortalamasının 3,95 olduğu, tutum son test puanları ortalamasının ise 3,85 olduğu görülmektedir. Kontrol grubunun Türkçe dersine yönelik tutum ön test ve son test puanları ortalamaları arasında anlamlı bir farkın olup olmadığı, bağımlı gruplar için t testi ile analiz edilmiş, hesaplanan t değeri ve \%95 güven aralığında anlamlılık düzeyine göre testler arasında anlamlı bir farklılık belirlenmemiştir $(t(28)=0,76 ; p>0,05)$. 
1.4. Deney grubunun Türkçe dersine yönelik tutum son test puanları ile kontrol grubunun Türkçe dersine yönelik tutum son test puanları arasında anlamlı farklılık var mıdır?

Tablo $6^{\prime}$ da, deney ve kontrol grubuna ait Türkçe dersine yönelik tutum son test puanları gösterilmiştir.

Tablo 6: Deney ve Kontrol Gruplarıın Türkşe Dersine Yönelik Tutum Son Test Puan Ortalamalarının Karşılaştııılmasına iliş̧kin Bağımsız Gruplar İ̧̧in t Testi Analiz Sonuçları

\begin{tabular}{lcccccc}
\hline Grup & $\mathrm{N}$ & $\bar{X}$ & $\mathrm{~S}$ & $\mathrm{sd}$ & $\mathrm{t}$ & $\mathrm{p}$ \\
\hline Deney & 27 & 4,07 & 0,45 & 54 & 1,69 & 0,10 \\
Kontrol & 29 & 3,85 & 0,55 & & & \\
\hline
\end{tabular}

Tablo 6 incelendiğinde, Türkçe dersine yönelik tutum son testi puan ortalamaları deney grubu için 4,07 , kontrol grubu öğrencilerinin son test puanları ortalaması 3,85'dir. Ayrıca deney grubunun standart sapması 0,45 , kontrol grubunun standart sapması 0,55 olarak bulunmuştur. Hesaplanan $\mathrm{t}$ değeri ve \%95'lik anlamlıık düzeyi göz önünde bulundurulduğunda Türkçe dersine yönelik tutum düzeyleri açısından deney ile kontrol grubunun son test puanları arasında anlamlı bir farklılık belirlenmemiştir $(t(54)=1,69 ; p>0,05)$. Ortalama ve standart sapma değerleri dikkate alındığında, deney grubunun Türkçe dersine yönelik tutum düzeyinin daha yüksek olduğu görülmektedir.

1.5. Deney grubunun Türkçe dersine yönelik tutum son test ve ön test puanları arasındaki fark puanları ile kontrol grubundaki öğrencilerin Türkçe dersine yönelik tutum son test ve ön test puanları arasındaki fark puanları arasında anlamlı farklılık var mıdır?

Tablo 7'de deney ve kontrol gruplarının Türkçe dersine yönelik tutum son test puan ortalamalarının farkları ile ön test puan ortalamalarının farkları arasındaki farklar görülmektedir.

Tablo 7: Deney ve Kontrol Gruplarının Türkçe Dersine Yönelik Tutum Son Test ve Ön Test Puan Ortalamaları Arasındaki Farkın t Testi Analiz Sonuçları

\begin{tabular}{lcccccc}
\hline Grup & $\mathrm{N}$ & $\overline{\mathrm{X}}$ & $\mathrm{S}$ & $\mathrm{sd}$ & $\mathrm{t}$ & $\mathrm{p}$ \\
\hline Deney & 27 & 0,79 & 0,59 & 54 & 5,14 & 0,00 \\
Kontrol & 29 & $-0,10$ & 0,69 & & & \\
\hline
\end{tabular}

Tablo 7 incelendiğinde, deney grubunun Türkçe dersine yönelik tutum ön test ve son test puan ortalamaları arasındaki fark 0,79 iken, kontrol grubunun, Türkçe dersine yönelik tutum ön test ve son test puan ortalamaları arasındaki fark $-0,10$ olmuştur. Ayrıca deney grubunun standart sapması 0,59, kontrol grubunun standart sapması 0,69 olarak bulunmuştur. Hesaplanan t değeri ve \%95 güven aralığı anlamlılık düzeyi göz önünde bulundurulduğunda Türkçe dersine yönelik tutum düzeyleri açısından deney tutum son test ve ön test puanları arasındaki fark ile kontrol tutum son test ve ön test puanları arasındaki fark açısından anlamlı bir farklılık olduğu belirlenmiştir $(t(54)=5,14$; 
$p<0,05)$. Ortalama ve standart sapma değerleri dikkate alındığında, bu farkın deney grubu lehine olduğu görülmektedir.

\section{Sonuç ve Tartışma}

Alt problemler doğrultusunda şu sonuçlara ulaşılmıştır:

Tablo 3'e göre, Türkçe dersine yönelik ön tutum puanlarına bakıldığında, deney grubundaki öğrencilerin ön tutum puanları ortalaması ile kontrol grubundaki öğrencilerin ön tutum puanları ortalamaları arasında anlamlı bir fark vardır.

Deney grubunda yer alan deneklerin, Türkçe dersine yönelik son tutum puanları aritmetik ortalamaları ile ön tutum puanları aritmetik ortalamaları arasında istatistiksel olarak anlamlı bir fark bulunmuştur. Tablo 4'ten de anlaşılacağı üzere yapılandırmacı yaklaşıma dayalı mizah uygulamaları deney grubundaki deneklerin Türkçe dersine yönelik tutumları üzerinde anlamlı düzeyde etkili olmuştur. Öğrencilerin deneysel işlem sonrası sahip oldukları tutumlarının deneysel işlemden önce sahip oldukları tutumlara göre ilerleme gösterdiği belirlenmiştir.

Kontrol grubunun Türkçe dersine yönelik son tutum puanları aritmetik ortalaması, ön tutum puanları aritmetik ortalamasına göre daha düşüktür. Tablo 5'e göre kontrol grubunun Türkçe dersine yönelik son tutum puanları ile ön tutum puanları arasındaki fark anlamlı değildir. Bu sonuca göre yapılandırmacı yaklaşıma dayalı karma yöntemlerin öğrencilerin Türkçe dersine yönelik tutumları üzerinde yapılandırmacı yaklaşıma dayalı mizah uygulamalarının kullanıldığı gruptaki gibi olumlu katkı sağlamadığı tespit edilmiştir.

Tablo 6'ya göre, istatistiksel analiz sonucunda, Türkçe dersine yönelik son tutum puanlarına bakıldığında, deney grubundaki öğrencilerin son tutum puanları ortalaması ile kontrol grubundaki öğrencilerin son tutum puanları ortalamaları arasında anlamlı bir fark yoktur. Tablo 7'ye göre, deney ve kontrol gruplarının Türkçe dersine yönelik tutum son test puan ortalamalarının farkları ile ön test puan ortalamalarının farkları arasındaki farklara bakıldığında aralarında istatistiksel olarak anlamlı bir fark olduğu görülmektedir.

Tablo 3 ve Tablo 6’ya göre deney grubu ile kontrol grubunun ön tutumları arasındaki anlamlı farkın deney grubu lehine kapanmış olması ve deney gurubunun son tutuma yönelik puanlarının kontrol grubundan daha yüksek olması, mizah kullanımının etkililiğinden kaynaklandığı şeklinde yorumlanmıştır.

Çelik'e $(2006,37)$ göre mizahla işlenen ders, derse yönelik tutumları da olumlu yönde etkilemektedir. Yapılan çalışmanın öğrencilerin fizik dersine yönelik tutumlarını geliştirmede etkili olduğu görülmüştür. Bilgisayar destekli mizah ile ders işleyen öğrencilerin son test puanları ortalaması, geleneksel yöntemle ders işleyen öğrencilerin son test puanlarının ortalamasından anlamlı bir şekilde yüksektir. Bu sonuca bağlı olarak bilgisayar destekli mizahın deney grubu denekleri üzerinde etkili olduğu, deneysel işlem öncesi sahip oldukları tutumlarının deneysel işlem sonrasında 
olumlu yönde arttığı belirlenmiştir.

Özalp (2006:55) de, mizahın bir ögesi olan karikatür kullanımının derse olan ilgiyi önemli ölçüde arttırdığını ifade etmektedir. Aydın (2006:164) tarafından yapılan çalışmada ise Türkçe dersine yönelik tutumlarda deney grubunun puanlarındaki artış, kontrol grubununkinden yüksek olmasına karşın gruplar arasında istatistiksel olarak anlamlı bir fark bulunmamıştır.

Yukarıda belirtilen sonuçlara göre yedinci sınıf Türkçe dersinde mizah kullanımı öğrencilerin tutumlarını olumlu yönde etkilemiştir. Mizah kullanımı (karikatür, resim, fıkra, espri, vd.) eğlendirirken düşündüren ve öğreten bir yöntemdir. Bu nedenle derslerde mizahın kullanılması öğrencilerin derslere olan tutumlarında olumlu değişiklikler yaratacaktır.

\section{Öneriler}

Bu çalışmada yapılandırmacı yaklaşıma dayalı mizah kullanımı öğrencilerin tutumlarını olumlu yönde etkilemiştir. Bu sonuçtan hareketle aşağıda bazı öneriler sunulmuştur.

Benzeri çalışmalar daha alt sınıflarda da yapılabilir. Bu doğrultuda Türkçe programında yeni düzenlemeler yapılabilir.

Mizahın, öğrencilerin derse yönelik tutumlarını olumlu yönde etkilediği sonucundan hareketle diğer derslerde de öğrencilerin derse yönelik tutumlarını olumlu yönde geliştirmek için kullanılabilir.

Eğitimde mizah kullanımının istendik sonuçlar doğurabilmesi için çocukta mizah duygusunun geliştirilmesi gerekmektedir. Mizah duygusunun gelişimi için çocuğun duygu ve düşüncelerini aktarabileceği özgür, eleştirel yaratıcı ortamların oluşturulması gerekir. Bu ortamlar içerisinde masal, fıkra, karikatür gibi mizah türlerinin çocukların yaşlarına uygun seviyede verilmesi de önemli görülmektedir.

\section{Kaynakça}

Akçay, A. ve Şahin, A. (2012) Webquest (Web Macerası) Öğrenme Yönteminin Türkçe Dersindeki Akademik Başarı ve Tutuma Etkisi, Eğitim Bilimleri Araştırmaları Dergisi, 2 (2), 33-45.

Akpınar, E. ve Ergin, Ö. (2005). Probleme Dayalı Öğrenme Yaklaşımına Yönelik Öğrenci Görüşleri. Inönü Üniversitesi Eğitim Fakültesi Dergisi, 6 (9), 3-14.

Akün, D. (1997). 9-11 Yaş Çocuklarında Mizah Duygusunun Gelişimi. İstanbul: Marmara Üniversitesi Eğitim Bilimleri Enstitüsü, Yayımlanmamış Yüksek Lisans Tezi.

Arslan, M. (2007). Eğitimde Yapılandırmacı Yaklaşımlar. Ankara Üniversitesi Eğitim Bilimleri Fakültesi Dergisi, 40 (1), 41-61.

Aydın, i. S. (2006). Türkçe Derslerinde Mizah Kullanımının Öğrenci Tutum ve Başarısına Etkisi (izmir ilköğretim 8. Sınıf Örnekleminde). İzmir: Dokuz Eylül Üniversitesi Eğitim Bilimleri Enstitüsü, Yayımlanmamış Doktora Tezi.

Büyüköztürk, ş. (2007). Sosyal Bilimler İ̧̧in Veri Analizi El Kitabı. (7.Basım). Ankara: Pegem AYayıncılık. 
Cantürk Günhan, B. (2006). Ilköğretim Il. Kademe Matematik Dersinde Probleme Dayalı Öğrenmenin Uygulanabilirliği Üzerine Bir Araştırma. İzmir: Dokuz Eylül Üniversitesi Eğitim Bilimleri Enstitüsü, Yayımlanmamış Doktora Tezi.

Çelik, E. (2006). Fizik Öğretiminde Bilgisayar Destekli Mizahın Öğrenci Başarısına ve Tutumuna Etkisi. Ankara: Ankara Üniversitesi Eğitim Bilimleri Enstitüsü, Yayımlanmamış Yüksek Lisans Tezi.

Demirel, Ö. (2004). Kuramdan Uygulamaya Eğitimde Program Geliştirme. Ankara: PegemA Yayıncılık.

Deveci, H. (2002). Sosyal Bilgiler Dersinde Probleme Dayalı Öğrenmenin Öğrencilerin Derse Ilişkin Tutumlarına, Akademik Başarılarına ve Hatırlama Düzeylerine Etkisi. Eskişehir: Anadolu Üniversitesi Eğitim Bilimleri Enstitüsü, Yayımlanmamış Doktora Tezi.

Durmaz, B. (2007). Yapılandırııı Fen Öğretiminde Kavram Karikatürlerinin Öğrencilerin Başarısı ve Duyuşsal Özelliklerine Etkisi (Muğla ili Merkez ilç̧e Örneği). Muğla: Muğla Üniversitesi Fen Bilimleri Enstitüsü, Yayımlanmamış Yüksek Lisans Tezi.

Durmuş, Y. (2000). The Relationship Between Sense of Humor and Coping Strategies (Mizah Duygusuyla Başa Çıkma Stratejileri Arasındaki Iliş̧ki). Ankara: Orta Doğu Teknik Üniversitesi Sosyal Bilimler Enstitüsü, Yayımlanmamış Yüksek Lisans Tezi.

Durualp, E. (2006). Ilköğretimde Sosyal Bilgiler Öğretiminde Karikatür Kullanımı. Ankara: Gazi Üniversitesi Eğitim Bilimleri Enstitüsü, Yayımlanmamış Yüksek Lisans Tezi.

Ergün, M. (2004). Sınıf Yönetimi. Emin Garip (Ed.), Sınıfta Motivasyon. Ankara: PegemA Yayıncılık.

İnam, A. ve Güleç, C. (2007). Metaforla Saadet Olmaz. E. Serbes (Haz.). (2.Basım). İstanbul: Say Yayınları.

İnceoğlu M. (2010). Tutum Algı Iletişim. (5.Basım). İstanbul: Beykent Üniversitesi Yayınevi.

İncioğlu, M. (2003). Utangaçlık Düzeyleri Farklı Lise Son Sınıf Öğrencilerinin Durumluk Mizah Tepki Düzeylerinin incelenmesi. Ankara: Hacettepe Üniversitesi Sosyal Bilimler Enstitüsü, Yayımlanmamış Yüksek Lisans Tezi.

Kara, Ö. T. (2011). Dramayla Öykü Oluşturma Yönteminin Türkçe Dersi II. Kademe Öğrencilerinin Tutumlarına Etkisi, Mustafa Kemal Üniversitesi Sosyal Bilimler Enstitüsü Dergisi, 8 (16), 239-253.

Karasar, N. (2000). Bilimsel Araştırma Yöntemi. Ankara: Nobel Yayın Dağıtım.

Kavcar, C. (1999). Edebiyat ve Eğitim. Ankara: Engin Yayıncılık.

Küçükbayındır, Z. (2003). The Effect of Humour Training on Job Satisfaction and Organisational Climate. İstanbul: Marmara Üniversitesi Sosyal Bilimler Enstitüsü, Yayımlanmamış Yüksek Lisans Tezi.

MEB. (2006). Ilköğretim Türkçe Dersi (6, 7, 8. Sınıflar) Öğretim Programı. Ankara: Milli Eğitim Bakanlığı Yayınları.

Morreall, J. (1997). Gülmeyi Ciddiye Almak. (Çev. Kubilay Aysevener, Şenay Soyer). İstanbul: İris Yayıncılık.

Oral, T. (1998). Yaza Çize. İstanbul: İris Yayıncılık.

Özalp, ı. (2006). Karikatür Tekniğinin Fen ve Çevre Eğitiminde Kullanılabilirliği Üzerine bir Araştırma. Manisa: Celal Bayar Üniversitesi Fen Bilimleri Enstitüsü, Yayımlanmamış Yüksek Lisans Tezi.

Özenç, S. (1998). Algılanan Anne-Baba Tutumlarının Durumluk Mizah Tepki Düzeyine Etkisi. Samsun: Ondokuz Mayıs Üniversitesi Sosyal Bilimler Enstitüsü, Yayımlanmamış Yüksek Lisans Tezi.

Özkan, H. i. (2008). Öğretmen ve Öğrencideki Mizah Anlayışının Sınıf Atmosferine Etkisi, Konya: Selçuk 
Üniversitesi Sosyal Bilimler Enstitüsü, Yayımlanmamış Yüksek Lisans Tezi.

Pilancı, H. (1998). Çağdaş Eğitimde Halk Edebiyatının Kullanılması. Eskişehir: Anadolu Üniversitesi Yayınları.

Savaş, S. (2009). IIlköğretim 7. Sınıf Türkçe Derslerinde Mizah Kullanımının Öğrenci Tutum Ve Başarısına Etkisi. Zonguldak: Zonguldak Karaelmas Üniversitesi Sosyal Bilimler Enstitüsü, Yayımlanmamış Yüksek Lisans Tezi.

Sever, S. (2003). Çocuk ve Edebiyat. Ankara: Kök Yayıncılık.

Tezbaşaran, A. (2008). Likert tipi Ölçek Geliştirme Kılavuzu. [Elektronik Sürüm]. Mersin.

Tümkaya, S. (2006). Öğretim Elemanlarının Mizah Tarzları ve Mizahı Yordayıcı Değişkenler. Eğitim Araştırmaları, 23, 200-208.

Topçuoğlu, H. (2007). Eğitimde Mizahın Önemi. Bilim ve Aklın Aydınlığında Eğitim Dergisi, 84, 38-43.

Topuz, S. (1995). The Relationships Among Popularity, Sense of Humor and Academik Achievement. Ankara: Orta Doğu Teknik Üniversitesi Sosyal Bilimler Enstitüsü, Yayımlanmamış Yüksek Lisans Tezi.

Üstün, Ö. (2007). Ortaöğretim Üçüncü Sınıfta Türk Dili ve Edebiyatı Dersinde Karikatür Kullanımının Yazılı Anlatım Öğretimine Etkisi. Çanakkale: Çanakkale Onsekiz Mart Üniversitesi Sosyal Bilimler Enstitüsü, Yayımlanmamış Yüksek Lisans Tezi.

Vural, A. (2004). Mizah ve Gülmenin Insan Yaşamındaki Yeri ve Önemi. Ankara: Ankara Üniversitesi Eğitim Bilimleri Enstitüsü, Yayımlanmamış Yüksek Lisans Tezi.

Yerlikaya, E. E. (2003). Mizah Tarzları Ölçeği'nin Uyarlama Çalışması. Adana: Çukurova Üniversitesi Sosyal Bilimler Enstitüsü, Yayımlanmamış Yüksek Lisans Tezi. 